\title{
La aplicación de la tecnología de los Microarrays en la oncología clínica
}

Khosravi Shahi P, Pérez Manga G. La aplicación de la tecnología de los Microarrays en la oncología clínica. An Med Interna (Madrid) 2006; 255256.

El estudio de las alteraciones genéticas (perfil genético) propias de cada tipo de neoplasia está adquiriendo cada vez mayor relevancia con la introducción de la tecnología de los microarrays del DNA y del RNA (1) (técnica que permite el estudio sincrónico de miles de genes expresados por un tumor), tanto desde punto de vista de la biología molecular en el entendimiento de la etiopatogenia de los procesos neoplásicos como desde punto de vista clínico, puesto que se ha establecido correlaciones estrechas entre la expresión determinados perfiles genéticos por las células neoplásicas y el pronóstico de la enfermedad. Dos de las neoplasias en las que mejor ha sido estudiado este fenómeno son el cáncer de mama y los linfomas.

El cáncer de mama incluye un grupo heterogéneo de neoplasias con una historia natural diferente. Los estudios más recientes mediante el empleo de la técnica de microarrays del DNA pone de manifiesto la existencia de tres grandes subtipos de carcinoma de mama infiltrante desde el punto de vista del perfil genético, con relevancia pronóstica y terapéutica (2): luminal (A, B y C), HER-2 positivo y "basal-like".

1. El subtipo luminal se caracteriza por una asociación a una alta expresión de receptores estrogénicos (RE) y a los genes regulados por los estrógenos, lo que proporciona una alta tasa de respuesta a la hormonoterapia y una mayor supervivencia.

2. El subtipo HER-2 positivo presenta el fenotipo RE negativo y se asocia con la sobreexpresión de genes relacionados con una mayor agresividad biológica. Este subtipo tiene un peor pronóstico, presentando una resistencia relativa a determinados agentes quimioterápicos (esquema $\mathrm{CMF}$ ) y al tamoxifeno (3).

3. El subtipo "basal-like" también es denominado el fenotipo triple negativo (receptores estrogénicos, progesterónicos y HER-2 negativos). En la mitad de los casos presentan una sobreexpresión de EGFR, y se asocian con hallazgos histopatológicos de mal pronóstico como alto grado, pleomorfismo o un alto índice mitótico. Es un subtipo de mal pronóstico, pero paradójicamente se asocia a una alta tasa de respuesta a la quimioterapia.
En cuanto a los linfomas, cabe destacar los avances que se han producido en el campo del linfoma B difuso de células grandes (LBDCG). Las alteraciones genéticas que definen el LBDCG son la presencia de:

1) Reordenamiento clonal de los genes de las cadenas pesadas de las inmunoglobulinas (PCR IgH positivo), lo que indica una monoclonidad de células B; 2) mutaciones hipersomáticas de los genes de las regiones variables (IgHV) de las cadenas pesadas de las Inmunoglobulinas, lo que indica un origen post-centrogerminal (derivan de células B del centrogerminal o un paso posterior en la diferenciación celular) (4); y 3) otras: como sobreexpresión de Bcl-2 (potente inhibidor de la apoptosis) (5) asociado o no a la traslocación t(14,18) (6) en un $30-40 \%$ 2, sobreexpresión de Bcl-6 por traslocaciones que afectan al 3q27 en un 30\% (7), expresión de p53 (17p), que se asocia a un peor pronóstico (8); y la traslocación $\mathrm{t}(8,14)$ con sobreexpresión del oncogén C-myc, presente en raros casos, sobre todo en los casos Burkitt-like.

En función del perfil genético se puede clasificar el LBDCG en tres grandes subtipos con relevancia pronóstica y terapéutica (9), mediante la técnica de DNA microarrays (Linfochip):

1. Subtipo 1. Células B centro germinal-like: es el subtipo de mejor pronóstico con una tasa de supervivencia a los 5 años de $60 \%$ y con una buena respuesta al tratamiento. Su perfil genético es similar a las células del centro germinal, con expresión de CD1, t(14,18), bcl-6, HGAL, CD38, el factor nuclear A-myb, la proteína de reparación del ADN 8-oxoguanina ADN glucosilasa y mutaciones somáticas de IgHV (10).

2. Subtipo 2. Células B activadas: es un subtipo de peor pronóstico, con una pobre respuesta al tratamiento, y supervivencia a los 5 años de $35 \%$. Suele presentar sobreexpresión de bcl-2, sin t(14,18), así como un perfil de expresión génica relacionado con células B activadas como MUM1/IRF4, ciclina D2, FLICE o CD44 (11).

3. Subtipo 3. LBDCG primario de mediastino: este subtipo es de mal pronóstico, con una supervivencia a los 5 años de $39 \%$. No expresa en alto grado ninguno de los perfiles génicos 
de los otros dos grupos anteriores, pero presenta ganancias y amplificaciones de 9p21-ter y 2p14-16 (12).

Por tanto, el futuro de la oncología clínica pasa por una mayor comprensión de la biología molecular de los tumores, y su aplicación a la práctica clínica.

\section{Bibliografía}

1. Raetz EA, Moos PJ. Impact of microarray technology in clinical oncology. Cancer Invest 2004; 22: 312-20.

2. O'Connell P. Genetic and cytogenetic analyses of breast cancer yield different perspectives of a complex disease. Breast Cancer Res Treat 2003; 78: 347-9.

3. Burstein HJ. The distinctive nature of HER2 of breast cancers. N Engl J Med 353; 16: 1652-1654.

4. Klein U, Goossens T, Fischer M, Kanzler H, Braeuninger A, Rajewsky $\mathrm{K}$, et al. Somatic hypermutation in normal and transformed human $\mathrm{B}$ cells. Immunol Rev 1998; 162: 261-280.

5. Korsmeyer SJ. BCL-2 gene family and the regulation of programmed cell death. Cancer Res 1999; 59: 1693s-1700s.

6. Huang JZ, Sanger WG, Greiner TC, Staudt LM, Weisenburger DD, Pickering DL, et al. The $t(14 ; 18)$ defines a unique subset of diffuse large Bcell lymphoma with a germinal center B-cell gene expression profile. Blood 2002; 99: 2285-2290.

7. Lo Coco F, Ye BH, Lista F, Corradini P, Offit K, Knowles DM, et al. Rearrangments of the BCL-6 gene in diffuse large cell non-Hodgkin's Lymphoma. Blood 1994; 83: 1757-1759.

\section{P. KHOSRAVI SHAHI, G. PEREZ MANGA}

\author{
Servicio de Oncología Médica. Hospital General \\ Universitario Gregorio Marañon. Madrid.
}

8. Ichikawa A, Kinoshita T, Watanabe T, Kato H, Nagai H, Tsushita K, et al. Mutations of the p53 gene as a prognostic factor in aggressive B-cell lymphoma. N Engl J Med 1997; 337: 529-534.

9. Alizadeh AA, Eisen MB, Davis RE, Ma C, Lossos IS, Rosenwald A, et al. Distinct types of diffuse large B-cell lymphoma identified by gene espression profiling. Nature 2000; 403: 503-511.

10. Lossos IS, Alizadeh AA, Esien MB, Chan WC, Brown PO, Botstein D, et al. Ongoing immunoglobulin somatic mutation in germinal center $\mathrm{B}$ cell-like but not in activated B cell-like diffuse large cell lymphomas. Proc Natl Acad Sci USA 2000; 97: 10209-13.

11. Monti S, Savage KJ, Kutok JL, Feuerhake F, Kurtin P, Mihm M, et al. Molecular profiling of diffuse large B-cell lymphoma identifies robust subtypes including one characterized by host inflammatory response. Blood 2005; 105: 1851-61.

12. Savage KJ, Monti S, Kutok JL, Cattoretti G, Neuberg D, De Leval L, et al. The molecular signature of mediastinal large B-cell lymphoma differs from that of other diffuse large B-cell lymphomas and shares features with classical Hodgkin lymphomas. Blood 2003. 